\title{
Amino acid exposure modulates the bioactivity of biofilms for larval settlement of Hydroides elegans by altering bacterial community components
}

\author{
Tao Jin, Pei-Yuan Qian* \\ Department of Biology, Hong Kong University of Science and Technology, Clear Water Bay, Kowloon, Hong Kong SAR
}

\begin{abstract}
Possible relationships among amino acids, bacterial community structure (in terms of relative abundance of bacterial species) of marine biofilms, and larval settlement of Hydroides elegans were investigated. Two day old biofilms were first exposed to 8 different amino acids for $24 \mathrm{~h}$. The bacterial abundance on the treated biofilms was then determined by epi-fluorescence microscopy, and the bacterial community profile was revealed through T-RFLP (terminal restriction fragment length polymorphism) analysis of the 16S rRNA gene. The larval settlement patterns on the treated biofilms were evaluated using laboratory bioassay. Aspartic acid and glutamic acid significantly increased bacterial abundance, modified the bacterial community structures on the biofilms, and elevated the inductive effect of the biofilms. Alanine and asparagine increased while isoleucine decreased the bioactivities of the biofilms by changing the bacterial species composition (not the bacterial abundance) of the biofilms. The other 3 amino acids (leucine, threonine, and valine) did not alter the bacterial community structures or bioactivities of the biofilms. By correlating the peaks of T-RPLP profiles with clone library results or pure bacterial strains isolated from biofilms, we partially identified the bacterial species on the biofilms that may enhance or inhibit larval settlement of $H$. elegans.
\end{abstract}

KEY WORDS: Hydroides elegans Larval settlement · Biofilm · Amino acid · Terminal restriction fragment length polymorphism $\cdot$ T-RFLP

\section{INTRODUCTION}

Larvae of many marine invertebrates settle in response to a wide range of natural cues that originate from conspecific or congeneric individuals (Crisp 1984, Pawlik 1992, Rodriguez et al. 1993, Matsumura et al. 1998, Qian 1999), sympatric species, food items, habitat (Pechenik et al. 1995, Bryan et al. 1998), or biofilms (Kirchman et al. 1982, Maki et al. 1989, O'Connor \& Richardson 1998, Unabia \& Hadfield 1999, Lau et al. 2002). Laboratory assays have suggested that some artificial cues can also induce larval settlement of different species (Pawlik 1990, Pechenik \& Qian 1998).

Among these cues, biofilms, which are complex agglomerates of bacteria, diatoms, protozoa, and fungi, have been thought to be an important source for larval settlement of many marine invertebrates (Wieczorek \&
Todd 1998). Many recent studies have focused on the chemical cues derived from biofilms, with particular emphasis on bacterial metabolites (Unabia \& Hadfield 1999, Harder et al. 2002). Bacteria in biofilms may stimulate, inhibit or not affect larval settlement, depending on the species of invertebrates and the bacteria of concern (Avelin et al. 1993, Leitz \& Wagner 1993, Lau \& Qian 2000). Previous studies have suggested that the effect of bacterial communities on larval settlement may be a function of bacterial abundance and species composition (Keough \& Raimondi 1996, Qian et al. 2003). Despite decades of research on the effects of biofilms on larval settlement, the relationship between variations in bacterial community structure (in terms of the relative abundance of bacterial species) on biofilms in response to environmental factors and possible effect on settling invertebrate larvae is poorly understood. 
The calcareous, tube-building serpulid polychaete Hydroides elegans is a major fouling organism in Hong Kong, and it is also abundant in other tropical and subtropical coastal fouling communities. Competent larvae of $H$. elegans can be induced to settle and metamorphose by bacterial film, dissolved free amino acids, inorganic ions or other cues (Pechenik \& Qian 1998, Harder \& Qian 1999, Unabia \& Hadfield 1999, Lau \& Qian 2001). A number of bacterial strains isolated from natural biofilms inhibited or induced larval settlement of $H$. elegans. Chemical cues extracted from bacteria were found to be both surface-associated and water-soluble (Harder et al. 2002). On the other hand, using a rigid bioassay-guided isolation and purification procedure, Harder \& Qian (1999) isolated and purified settlement-inducing compounds from adult homogenates, conditioned seawater of $H$. elegans as well as naturally released leachate of Bugula neritina, a typical settlement location for $H$. elegans. These compounds were identified as a group of dissolved free amino acids. Beckmann et al. (1999) found that amino acid mixtures could promote biofilm development in testing dishes, which in turn triggered larval settlement, suggesting a triangular mode-of-action among cues, competent larvae and biofilms. Further study showed that amino acids induce larval settlement of $H$. elegans both directly and indirectly; certain amino acids promote biofilm development while others do not change bacterial abundance on the biofilm during larval settlement bioassay (Jin \& Qian 2004). However, it is unknown how different amino acids affect bacterial community structures and how changes of bacterial community structures in biofilm affect a biofilm's bioactivity in larval settlement induction.

In this study, the relationships among amino acids, biofilms, and larval settlement of Hydroides elegans were investigated. Specifically, the effects of single amino acids on the bacterial community structure of biofilms and the consequent effects on larval settlement of $H$. elegans were examined in detail. In addition, by construction of a clone library with a partial sequence of the 16S rRNA gene, we sought to identify the bacterial species on the biofilm, and especially the bacteria that were affected by amino acid incubation and might change larval settlement pattern.

\section{MATERIALS AND METHODS}

Larval culture. Adult Hydroides elegans were collected from PVC panels placed $3 \mathrm{~m}$ below the water surface at Long Harbor, Hong Kong $\left(22^{\circ} 24^{\prime} \mathrm{N}\right.$, $\left.114^{\circ} 21^{\prime} \mathrm{E}\right)$. Larvae were obtained from adults and reared to be competent according to the methods described by Jin \& Qian (2004). Larval competence to settlement was tested by exposing the larvae to a welldeveloped natural marine biofilm. Competent larvae attached to the surface of dishes within 1 to $2 \mathrm{~h}$ and metamorphosed within $12 \mathrm{~h}$. All larval settlement bioassays were performed with 5 to $6 \mathrm{~d}$ old larvae after fertilization.

Expt 1: Effect of biofilm age on larval settlement. Biofilms were developed on the Petri dishes (Falcon \#1006) placed $3 \mathrm{~m}$ below the surface at the HKUST pier located in Port Shelter $\left(22^{\circ} 19^{\prime} \mathrm{N}, 114^{\circ} 16^{\prime} \mathrm{E}\right)$, a bay in Hong Kong's waters. The duration for biofilm development varied from 1 to $4 \mathrm{~d}$. The filmed Petri dishes were collected, rinsed twice with $0.22 \mu \mathrm{m}$ filtered seawater (FSW), and used in the bioassays. There were 8 replicates for the control and each treatment, 5 for larval bioassay and 3 for enumeration of bacteria in the biofilms.

Expt 2: Effect of amino acid-treated biofilms on larval settlement. Eight amino acids (alanine, aspartic acid, asparagine, glutamic acid, isoleucine, leucine, valine, and threonine) were dissolved individually in FSW, at a concentration of $10^{-3} \mathrm{M}$ each. Based on the results of Expt 1, 2 d old biofilms were used in Expt 2. The Petri dishes coated with biofilms were rinsed twice with FSW and filled with $5 \mathrm{ml}$ of amino acid solution. In the control, $5 \mathrm{ml}$ of FSW was added to the dishes coated with $2 \mathrm{~d}$ old biofilms. After $24 \mathrm{~h}$, the solutions or FSW were poured out and the Petri dishes were rinsed twice with FSW and used for different bioassays. There were 11 replicates for each treatment and the control, 5 for larval settlement bioassay, 3 for enumeration of bacteria in the biofilms, and 3 for extraction of bacterial DNA.

Larval settlement bioassay. Twenty competent larvae and $4.5 \mathrm{ml}$ of FSW were pipetted into Petri dishes prepared as described above. The dishes were incubated at $30^{\circ} \mathrm{C}$ for $24 \mathrm{~h}$. The number of larvae that settled was determined under a dissecting microscope. Larvae that attached to the surface of the dish, and produced tentacles and a calcareous tube were considered as successful settlers. In all larval settlement bioassays, clean dishes (CD) containing FSW served as a negative control.

Enumeration of bacteria in biofilms. Bacteria were visualized with DNA-binding fluorochrome 4, 6-diamidino-2-phenylindole (DAPI, Fluka Chemie). Briefly, the Petri dishes under investigation were emptied and immersed in a $0.22 \mu \mathrm{m}$ filtered solution of $3 \%$ formaldehyde in FSW for $10 \mathrm{~min}$, rinsed with distilled water, and then stained with DAPI at a concentration of $0.5 \mu \mathrm{g} \mathrm{ml}{ }^{-1}$ for $5 \mathrm{~min}$ at room temperature. The mean density of the bacteria was determined under a fluorescence microscope (ZEISS Axiophot fluorescence microscope) at $1000 \times$ magnification, based on counts of 10 randomly chosen fields of view for each Petri dish. 
DNA extraction and polymerase chain reaction (PCR). Biofilms were scraped off the dishes $\left(\sim 20 \mathrm{~cm}^{2}\right)$ with sterile glass cover slip and suspended in $0.8 \mathrm{ml}$ of lysis buffer $(1 \%$ Triton X-100, $20 \mathrm{mM}$ Tris-HCl at pH 8, 2 mM EDTA). Total DNA was extracted and purified according to the SDS-based method described by Zhou et al. (1996). PCR of the 16S rRNA genes in the bacterial community DNA was performed in a total volume of $25 \mu \mathrm{l}$ containing $1 \mu \mathrm{l}$ of DNA template, $250 \mathrm{mM}$ of each deoxyribonucleotide triphosphate (dATP, dCTP, dGTP, dTTP; Pharmacia Biotechnology, USA), 1 U of buffered AmpliTaq Gold ${ }^{\mathrm{TM}}$ DNA polymerase (Applied Biosystems), $1.5 \mathrm{mM} \mathrm{MgCl}_{2}$, and $1 \mu \mathrm{M}$ of each universal primer: $341 \mathrm{~F}$ (5'-CCTACGGGAGGCAGCAG-3') and 926R-Fam (5'-CCGTCAATTCCTTTRAGTTT-3'). The 926R-FAM was fluorescently labeled at the $5^{\prime}$ end. PCR was performed at $94^{\circ} \mathrm{C}$ for $4 \mathrm{~min}$; 35 cycles of $94^{\circ} \mathrm{C}$ for $1 \mathrm{~min}, 55^{\circ} \mathrm{C}$ for $1 \mathrm{~min}, 72^{\circ} \mathrm{C}$ for $1 \mathrm{~min}$, and $72^{\circ} \mathrm{C}$ for $7 \mathrm{~min}$. Amplification of the DNA was verified by electrophoresis of $5 \mu \mathrm{l}$ of PCR products in $1.5 \%$ agarose in $1 \times$ TAE buffer.

Terminal restriction fragment length polymorphism (T-RFLP) analysis of bacterial communities. Ten microliters of PCR products were digested with $20 \mathrm{U}$ MspI (Boehringer Mannheim Biochemicals) at $37^{\circ} \mathrm{C}$ for $6 \mathrm{~h}$. Digested amplicons were purified with the Wiz$\operatorname{ard}^{\circledR}$ PCR preps DNA purification system (Promega, USA) according to the manufacturer's protocol. Aliquots of purified products $(10 \mu \mathrm{l})$ were mixed with $0.5 \mu \mathrm{l}$ of internal size standard (ET-550, Amersham). This mixture was denatured for $5 \mathrm{~min}$ at $95^{\circ} \mathrm{C}$ and immediately chilled on ice before electrophoresis on a MegaBACE ${ }^{\mathrm{TM}} 500$ genetic analyzer (Amersham Biosciences) operated in the Genotyping mode. After electrophoresis, the length of the fluorescently labeled terminal restriction fragments (T-RFs) was determined by comparison with internal standards using Fragment Profiler software (Amersham Biosciences). In each sample, terminal fragments $<50 \mathrm{bp}$ and $>500 \mathrm{bp}$ were excluded from the analysis to avoid detection of primers and uncertainties in size determination.

Clone library construction. Two day old natural biofilm was collected and the bacterial DNA of the biofilms was extracted following the same method as described above. PCR was performed with the primers $341 \mathrm{~F}$ and $926 \mathrm{R}$. The reaction condition was the same as described above. Purified PCR products were ligated into the pMD $18 \mathrm{~T}$-vector (Sangon). The hybrid vectors were used to transform Escherichia coli XL1-blue competent cells. Recombinants were selected by using X-Gal (5-bromo-4-chloro-3-indolyl- $\beta$-D-galactopyranoside)-IPTG (isopropyl- $\beta$-D-thio-alactopyranoside) indicator Luria-Bertani agar plates supplemented with $50 \mu \mathrm{g}$ of ampicillin per ml. The clones containing a $600 \mathrm{bp}$ insert were selected for sequencing.
Sequencing was performed on a MegaBACE ${ }^{\mathrm{TM}} 500$ genetic analyzer (Amersham Biosciences) with the M13 universal and M13 reverse sequencing primers. The nucleotide sequences were compared with those from the GenBank using BLASTn in the NCBI server. The partial 16S rRNA gene sequences were available in the GenBank under the accession numbers AY600921-AY600954.

Enzyme cut site analysis. The partial sequences of 16S rRNA gene from clone library were submitted to the online program NEBcutter V2.0 (tools.neb.com/ NEBcutter2/index.php) to cleave with the restriction enzyme MspI. To compare results with the T-RFLP results, the terminal restriction fragment lengths from the $3^{\prime}$ end were calculated because the reverse primer for T-RFLP analysis was fluorescently labeled.

Some pure bacterial strains isolated from natural biofilms at the same study site were chosen for NEBcutter analysis. The corresponding partial sequences of $16 \mathrm{~S}$ rRNA gene were selected and submitted to the program.

Statistical analysis. Statistical analyses were carried out using the SPSS statistics package. Data in the form of percentage of larval settlement were arcsine-transformed prior to statistical analysis. The replicates with zero larval settlement were given the value of $1 / 4 n$ ( $n=$ number of larvae in a single treatment) to improve the arcsine transformation (Zar 1999). The normality assumption was verified with Shapiro-Wilk's $W$-test (Shapiro \& Wilk 1965). Data that met the normality assumption of parametric tests were analyzed using 1-way ANOVA followed by Dunnett's test.

\section{RESULTS}

\section{Expt 1: Effect of biofilm age on larval settlement}

The percentage of larval settlement of Hydroides elegans increased with the age of the biofilm (Fig. 1A). The percentages of settlement were significantly higher in all dishes with a biofilm than in clean dishes. One day old biofilm induced $49 \%$ of larval settlement while $4 \mathrm{~d}$ old biofilm induced $78 \%$ of larval settlement. Bacterial abundance in the biofilms also increased over time from $5490 \pm 1211$ to $32700 \pm$ 4945 cells $\mathrm{mm}^{-2}$ within 4 d (Fig. 1B).

\section{Expt 2: Effect of amino acid-treated biofilms on larval settlement}

Biofilms treated with different amino acids induced different percentages of larval settlement of Hydroides elegans (Fig. 2A). The percentages of larval settlement on the biofilms treated with alanine, aspartic 

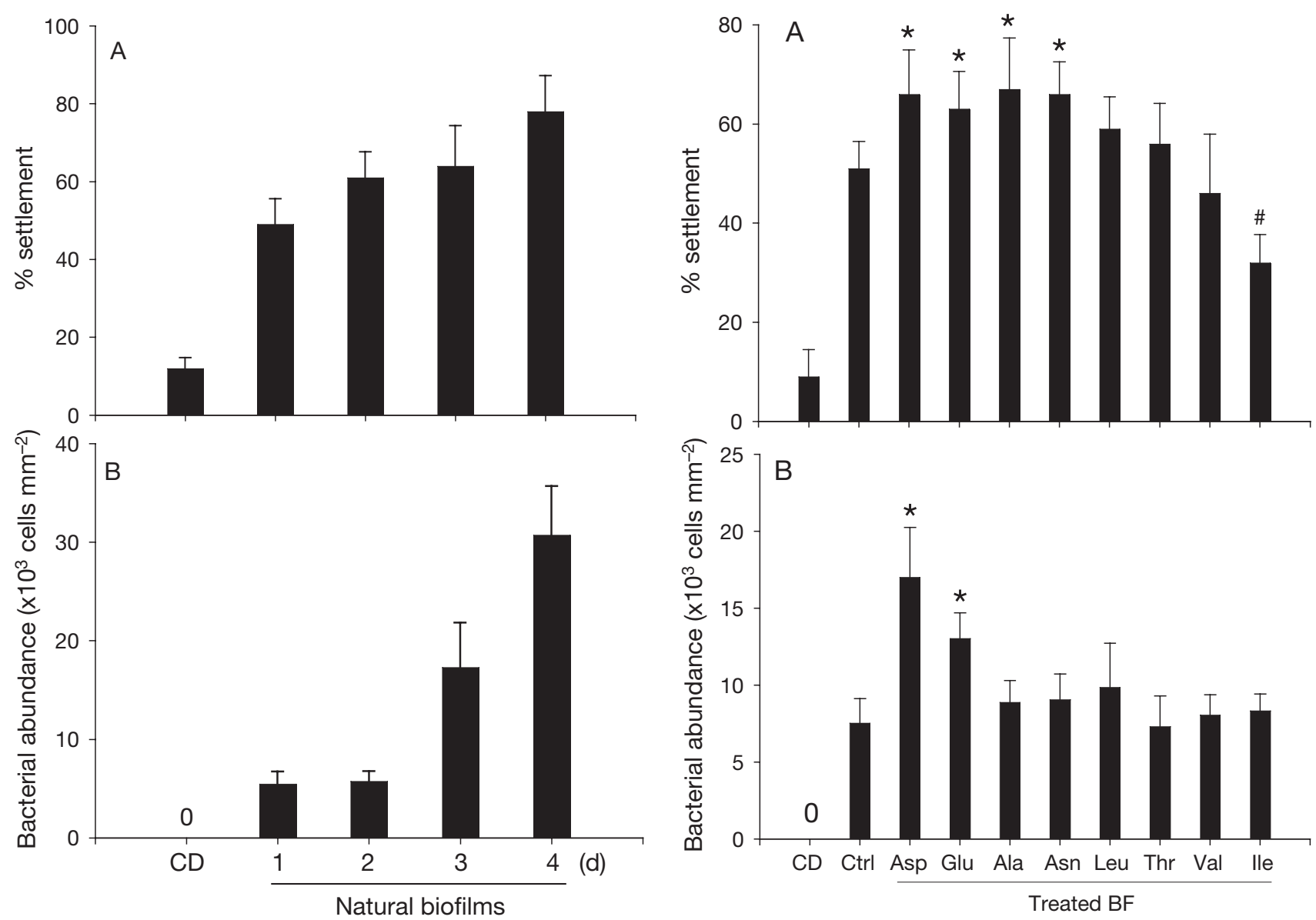

Fig. 1. Hydroides elegans. (A) Percentage of settled larvae in response to 1 to $4 \mathrm{~d}$ old natural biofilms. Data plotted are mean + SD of 5 replicates. (B) Bacterial abundance in 1 to $4 \mathrm{~d}$ old natural biofilm. Data plotted are mean + SD of 3 replicates. CD: clean dish

acid, asparagine or glutamic acid were significantly higher than those without amino acid treatment (i.e. control biofilm). The biofilms treated with leucine, threonine or valine induced a percentage of larval settlement similar to the control. The percentage of larval settlement on the biofilm treated with isoleucine was significantly lower than that on the control biofilm. In the biofilms treated with aspartic acid or glutamic acid, the bacterial densities were significantly higher than the bacterial densities on the control biofilm (Fig. 2B). In the other 6 treatments, including alanine and aspartic acid, the bacterial densities were the same as those on the control biofilm.

Bacterial communities in the control biofilm and in the biofilms treated with different amino acids displayed different T-RF patterns (Fig. 3). Here, only 1 replicate was shown because the profiles of different replicates were almost the same. The details of T-RFs

Fig. 2. Hydroides elegans. (A) Percentage of settled larvae in response to biofilms (BF) treated with aspartic acid (Asp), glutamic acid (Glu), alanine (Ala), asparagine (Asn), leucine (Leu), threonine (Thr), valine (Val), and isoleucine (Ile), respectively. Data plotted are mean $+\mathrm{SD}$ of 5 replicates. (B) Bacterial abundance in the amino acid treated biofilm. Data plotted are mean + SD of 3 replicates. Data that are significantly higher or lower than that in the control (Ctrl) at $\alpha=0.05$ in Dunnett's test are indicated by * or \# above the bars, respectively. CD: clean dish

are presented in Table 3. Some T-RFs were found in only some of the samples. For instance, the T-RFs of 143 and 144 bp were present only in the Asp-, Glu-, Ala-, and Asn-treated biofilms. A distinct T-RF of $183 \mathrm{bp}$ was found only in the Ile-treated biofilms. T-RFs of $301,314,372,375$, and $423 \mathrm{bp}$ were found in all the samples.

\section{Clone library construction}

A total of 178 clones were screened and 33 distinct 16S rRNA gene sequences were obtained. A comparison of these sequences to the DNA sequences in the 
GenBank database is given in Table 1. Comparative sequence analysis of these cloned sequences revealed that 14 were $\alpha$-Proteobacteria, 5 were $\gamma$-Proteobacteria, 9 were Cytophaga-Flexibacteria-Bacteroides (CFB), 2 were Cyanobacteria and 3 were other types of bacteria.

\section{Enzyme cut site analysis}

The results of the NEBcutter analysis with the sequences from the clone library are also given in Table 1. The results show that sequences from different bacteria may have the same T-RF. For instance, 10

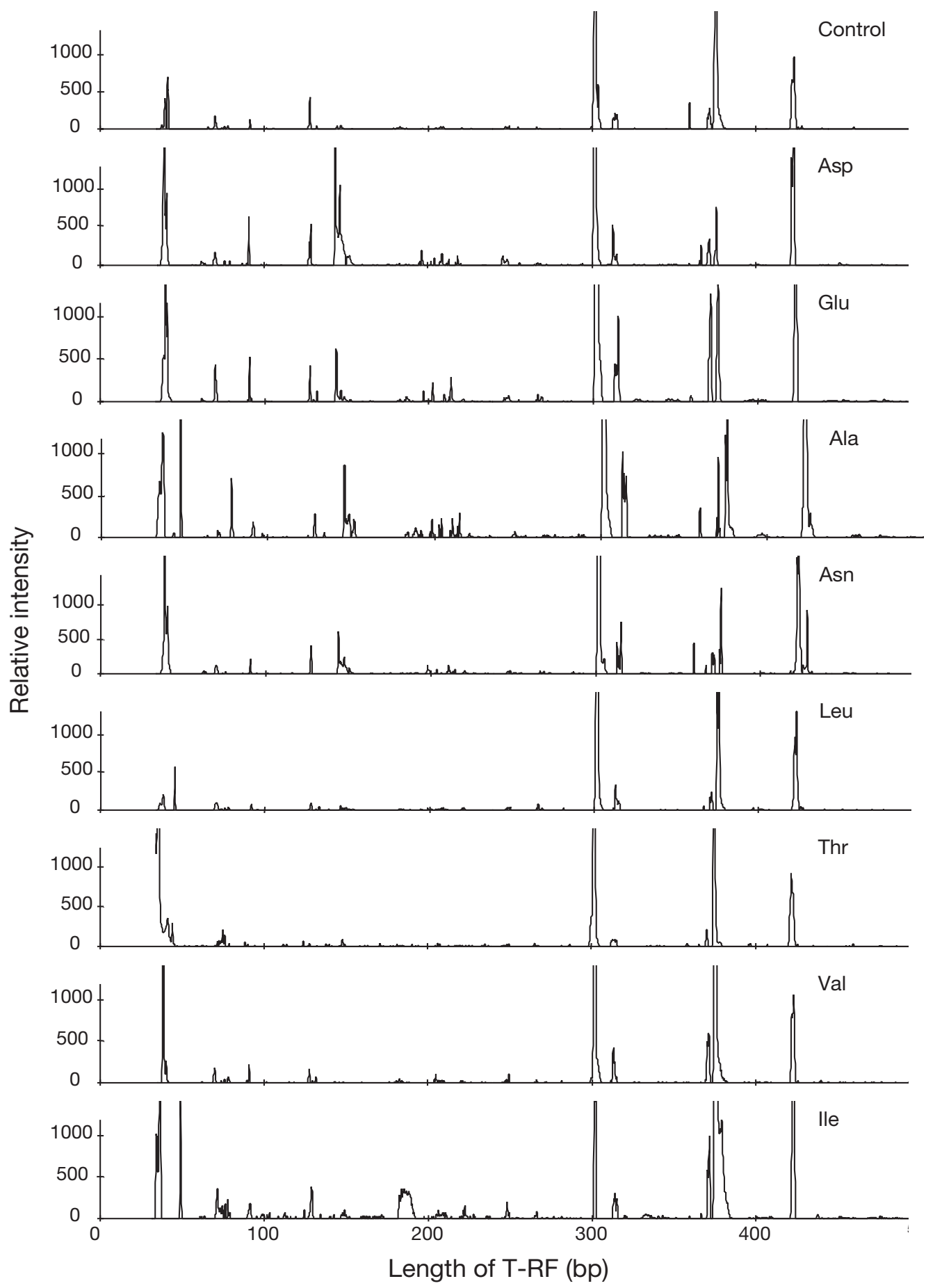

Fig. 3. Representative electropherograms of T-RFs derived from MspI digestion of PCR-amplified bacterial community DNA obtained from the biofilm treated with aspartic acid (Asp), glutamic acid (Glu), alanine (Ala), asparagine (Asn), leucine (Leu), threonine (Thr), valine (Val), and isoleucine (Ile), respectively 
different sequences share the same T-RF of $300 \pm 1 \mathrm{bp}$ and all these clones are $\alpha$-Proteobacteria. Six clones from the CFB group showed the same T-RF of $368 \pm$ $1 \mathrm{bp}$.

Table 2 presents the information on the pure bacterial strains isolated from natural biofilms at the study site, the results of the NEBcutter analysis, and the activity on the larval settlement of Hydroides elegans. The results follow the same trends as in Table 1 in which the bacteria sharing the same T-RF fall into the same phylogenetic branch.

\section{DISCUSSION}

In Expt 1, we found that the bacterial abundance and the inductive effect of biofilms on larval settlement of Hydroides elegans increased with the age of the biofilm developed in seawater. Compared to the other treatments, 2 d old natural biofilms were moderately inductive to larval settlement of $H$. elegans and the bacterial abundance was relatively low. We considered $2 \mathrm{~d}$ old biofilm to be the most suitable for Expt 2 since changes in both bioactivity and bacterial abundance of these biofilms could be better seen when treated with amino acids. Indeed, treatment with specific amino acids for $24 \mathrm{~h}$ changed the total bacterial abundance and bacterial community profiles on $2 \mathrm{~d}$ old biofilm.

Our results showed that Asp and Glu treatment significantly increased the bacterial abundance in the biofilms, but the other treatments did not. As shown in previous work as well as in Expt 1, the competent larvae of Hydroides elegans were quite sensitive to the bacterial abundance of biofilms (Keough \& Raimondi 1996, Lau \& Qian 2001). Therefore, an increase in bacterial abundance could be one of the reasons that the bioactivity of biofilms for larval settlement changes when biofilms are exposed to specific amino acids. It has been reported that a specific bacterium or bacterial group may utilize only 1 or several amino acids (Garner et al. 2002, Sass \& Cypionka 2004).

Table 1. Phylogenetic affiliations and NEBcutter analysis results of the 16S rRNA sequences from a clone library constructed for 2 d old marine natural biofilm. CFB: Cytophaga-Flexibacteria-Bacteroides

\begin{tabular}{|c|c|c|c|c|}
\hline $\mathrm{T}-\mathrm{RF}$ & Clone name & Closest match in GenBank & Phylogenetic branch & Similarity $(\%)$ \\
\hline 31 & $\mathrm{~J}-76$ & Uncultured bacterium (AY193144.1) & $\mathrm{CFB}$ & 96 \\
\hline 32 & $\mathrm{~J}-136$ & Uncultured gamma proteobacterium (AY225637.1) & $\gamma$-Proteobacteria & 98 \\
\hline 92 & $\mathrm{~J}-155$ & Erythrobacter sp. (AB012062.1) & $\alpha$-Proteobacteria & 99 \\
\hline 130 & $\mathrm{~J}-50$ & Leptospira santarosai (LS16SRDNX) & Spirochaetes & 89 \\
\hline 130 & $\mathrm{~J}-70$ & Unidentified gamma proteobacterium (AB015583.1) & $\gamma$-Proteobacteria & 97 \\
\hline 182 & $\mathrm{~J}-34$ & Uncultured Rhodobacter group bacterium (AF259637) & $\alpha$-Proteobacteria & 96 \\
\hline 205 & $\mathrm{~J}-15$ & Uncultured bacterium (AF523878.1) & $\alpha$-Proteobacteria & 96 \\
\hline 247 & $\mathrm{~J}-36$ & Uncultured marine eubacterium (AF159647) & unknown & 98 \\
\hline 247 & $\mathrm{~J}-59$ & Planktothricoides raciborskii (AB045960.1) & Cyanobacteria & 95 \\
\hline 247 & $\mathrm{~J}-147$ & Synechococcus sp. (AY172810.1) & Cyanobacteria & 99 \\
\hline 300 & $\mathrm{~J}-29$ & Uncultured eubacterium (AB047139.1) & $\alpha$-Proteobacteria & 98 \\
\hline 300 & $\mathrm{~J}-32$ & Uncultured bacterium (AF382114.1) & $\alpha$-Proteobacteria & 93 \\
\hline 300 & $\mathrm{~J}-35$ & Uncultured Rhodobacter group bacterium (AF259624) & $\alpha$-Proteobacteria & 97 \\
\hline 300 & $\mathrm{~J}-46$ & Alpha proteobacterium (AB026194.1) & $\alpha$-Proteobacteria & 98 \\
\hline 300 & $\mathrm{~J}-89$ & Silicibacter lacuscaerulensis (SLU77644) & $\alpha$-Proteobacteria & 97 \\
\hline 300 & $\mathrm{~J}-100$ & Uncultured bacterium (AY354144.1) & $\alpha$-Proteobacteria & 93 \\
\hline 300 & $\mathrm{~J}-131$ & Roseobacter sp. (AF107210) & $\alpha$-Proteobacteria & 98 \\
\hline 300 & $\mathrm{~J}-143$ & Uncultured Ruegeria CtaxMed-21 (AF259606) & $\alpha$-Proteobacteria & 98 \\
\hline 300 & $\mathrm{~J}-154$ & Bacterium K2-53B (AY345413.1) & $\alpha$-Proteobacteria & 98 \\
\hline 301 & $\mathrm{~J}-96$ & Uncultured bacterium (AF468275.1) & $\alpha$-Proteobacteria & 97 \\
\hline 313 & $\mathrm{~J}-44$ & Gamma proteobacterium (AY173441.1) & $\gamma$-Proteobacteria & 92 \\
\hline 313 & $\mathrm{~J}-118$ & Lucina floridana gill symbiont (L25707.1) & $\gamma$-Proteobacteria & 93 \\
\hline 314 & $\mathrm{~J}-68$ & Candidatus Endobugula sertula (AY173431.1) & $\gamma$-Proteobacteria & 92 \\
\hline 364 & $\mathrm{~J}-121$ & Uncultured Cytophagaceae bacterium (AY094494.1) & CFB & 91 \\
\hline 364 & $\mathrm{~J}-17$ & Tenacibaculum cellulophagum (AF469612.1) & CFB & 98 \\
\hline 367 & $\mathrm{~J}-40$ & Marine CFB-group bacterium MBIC01599 (AB086624.1) & CFB & 86 \\
\hline 367 & $\mathrm{~J}-116$ & Marine bacterium SCRIPPS_413 (AF359548) & CFB & 94 \\
\hline 368 & $\mathrm{~J}-57$ & Bacterium DG890 (AY258122.1) & CFB & 93 \\
\hline 368 & $\mathrm{~J}-95$ & Marine bacterium (AF359548) & CFB & 95 \\
\hline 368 & $\mathrm{~J}-111$ & Uncultured Bacteroidetes bacterium (AB116465.1) & $\mathrm{CFB}$ & 96 \\
\hline 368 & $\mathrm{~J}-132$ & Uncultured bacterium (AY354148.1) & CFB & 92 \\
\hline 372 & $\mathrm{~J}-94$ & Uncultured bacterium (AY212634.1) & Unknown & 99 \\
\hline 432 & $\mathrm{~J}-48$ & Uncultured alpha proteobacterium (AF473921.1) & $\alpha$-Proteobacteria & 98 \\
\hline
\end{tabular}


Table 2. NEBcutter analysis results with the partial 16S rRNA sequence from the pure bacterial strains and the activity of these bacteria on larval settlement of Hydroides elegans. The closest match for each bacterial strain is indicated by the strain name and accession number. CFB: Cytophaga-Flexibacteria-Bacteroides

\begin{tabular}{|c|c|c|c|}
\hline T-FR & Closest match at GenBank & Phylogenetic branch & Activity on larval settlement \\
\hline 128 & Pseudoalteromonas sp. UST010723-006 (AY241401) & $\gamma$-Proteobacteria & Inductive \\
\hline 207 & Shewanella algae (AY241408) & $\gamma$-Proteobacteria & Neutral \\
\hline 207 & Vibrio alginolyticus (AF343931) & $\gamma$-Proteobacteria & Inductive \\
\hline 207 & Vibrio fluvialis (X76335) & $\gamma$-Proteobacteria & Inductive \\
\hline 207 & Vibrio furnissii (AY241404) & $\gamma$-Proteobacteria & Neutral \\
\hline 207 & Vibrio sp. Ex25 UST010723-015 (AY241409) & $\gamma$-Proteobacteria & Inhibitive \\
\hline 207 & Vibrio tubiashii (X74725) & $\gamma$-Proteobacteria & Inductive \\
\hline 300 & Roseobacter sp. (SCB28) (U64005) & $\alpha$-Proteobacteria & Inductive \\
\hline 300 & Uncultured Ruegeria CtaxMed-2 (AY241403) & $\alpha$-Proteobacteria & Inductive \\
\hline 303 & Micrococcus kristinae (AY241411) & Gram-positive & Inhibitive \\
\hline 303 & Kocuria rhizophil (AY241412) & Gram-positive & Inhibitive \\
\hline 303 & Micrococcus sp. (AY241455) & Gram-positive & Inhibitive \\
\hline 304 & Bacillus licheniformis (AY241399) & Gram-positive & Inductive \\
\hline 304 & Vibrio halioticoli (AB000392) & $\gamma$-Proteobacteria & Inductive \\
\hline 304 & Vibrio nereis (X74716) & $\gamma$-Proteobacteria & Neutral \\
\hline 312 & Pseudoalteromonas piscicida (AY241415) & $\gamma$-Proteobacteria & Inhibitive \\
\hline 313 & Alteromonas alvinellae (AF288360) & $\gamma$-Proteobacteria & Neutral \\
\hline 313 & Alteromonas macleodii (AJ456961) & $\gamma$-Proteobacteria & Inductive \\
\hline 313 & Pseudoalteromonas sp. UST981101-005 (AF343926) & $\gamma$-Proteobacteria & Inductive \\
\hline 313 & Pseudoalteromonas sp. UST981101-017 (AF343936) & $\gamma$-Proteobacteria & Inductive \\
\hline 313 & Pseudoalteromonas sp. UST981101-033 (AF343949) & $\gamma$-Proteobacteria & Inductive \\
\hline 366 & Tenacibaculum mesophilum (AY241447) & CFB & Inhibitive \\
\hline 372 & Bacillus halmapal (AF343922) & Gram-positive & Inductive \\
\hline 372 & Staphylococcus cohnii (AY241414) & Gram-positive & Neutral \\
\hline 372 & Cytophaga sp. F12 (AF343927) & $\mathrm{CFB}$ & Inductive \\
\hline 423 & Microbulbifer hydrolyticus (AY241407) & $\gamma$-Proteobacteria & Inhibitive \\
\hline
\end{tabular}

We found that T-RFs of 143 and $144 \mathrm{bp}$ were present only in the Asp-, Glu-, Ala-, and Asn-treated biofilms, which had significantly higher inductive effects for larval settlement than the control biofilms had. These results suggest that these 4 amino acids promoted growth of specific bacteria/bacterium (such as the bacteria/bacterium represented by T-RFs of 143 and $144 \mathrm{bp}$ ) and thus modified the bacterial community structures in the biofilm. If such bacteria have inductive effects on larval settlement of Hydroides elegans, an increase in their relative abundance may enhance the bioactivity of the biofilms for larval settlement. Of course, in the Asp- and Glu-treated biofilms, it was unclear whether the increased larval settlement was due to an increase in total bacterial abundance or changes of bacterial community structure or both.

The T-RFLP profiles of bacterial communities in Leu-, Thr- or Val-treated biofilms were very similar to those in the control biofilms. We did not find any distinct T-RF present in these treatments. The results of the larval settlement bioassays indicated that the bioactivity of the biofilms did not change significantly. We concluded that these 3 amino acids had no indirect effect on the larval settlement of Hydroides elegans in the laboratory bioassay.
Interestingly, the inductive effect of the Ile-treated biofilm on the larval settlement of $H$. elegans decreased when compared to the control. We did not see a significant difference in the bacterial abundance between Ile-treated biofilm and the control. However, a distinct T-RF of 183 bp was found only in the Iletreated biofilm but not in other treatments or in the control. No cultivable bacteria in our culture collection match this T-RF peak. This distinct peak indicated that increase of relative density of this particular bacterium or bacterial group might inhibit larval settlement of H. elegans.

Previous work (Jin \& Qian 2004) suggested that Asp, Glu, Ala, Asn, Leu, Thr and Val could induce larval settlement of Hydroides elegans directly and Ile could not. In the present study, these amino acids showed different effects on bacterial communities of biofilms and the competent larvae of $H$. elegans responded variously to the modified biofilms. It is possible that the competent larvae of $H$. elegans may have sensory organs or specific receptors that can be triggered by different amino acids or cues derived from different bacteria that utilize different free amino acids as nutrients for growth, leading to changes in both the bacterial communities and the biofilm bioactivity for larval settlement of $H$. elegans. 
Biofilms cover all submerged substrata and mediate larval settlement of many marine invertebrates, thus influencing the habitat selection of these species. It has been reported that larvae are able to distinguish between biofilms developed under different conditions or in different locations (Pearce \& Scheibling 1991, Keough \& Raimondi 1996, Qian et al. 2003, Lau et al. 2005). Hydroides elegans larvae favor settling on the bryozoans Bugula neritina and conspecific worms juveniles and adults although adult $H$. elegans can feed settling larvae (Bryan et al. 1997). It was found previously that the leachate of $H$. elegans and $B$. neritina contains measurable amino acids (around $10^{-5} \mathrm{M}$ in total) (Harder \& Qian 1999). The results of the present study suggest that these amino acids may be one factor that leads to the formation of distinct and attractive biofilms on the surface of juvenile and adults of both $H$. elegans and B. neritina. Thus, amino acid components in the leachate of $H$. elegans and $B$. neritina may have both direct and indirect effects on larval settlement of $H$. elegans. As adults of $H$. elegans and $B$. neritina often aggregate in natural environments, the colonies can release reasonably high concentration of amino acids that may selectively promote the development of 'specific' bacterial films right on or next to the colonies. The changes in flow dynamics near the colonies may further enhance the concentrating effects of the amino acids to further promote biofilm development and even directly induce $H$. elegans to settle. Well-developed biofilms become very attractive to settling larvae of $H$. elegans, and as a result, they can further aggregate to form even large colonies. In fact, the complex interactions among biofilm, chemical cues and settling larvae may be applicable to the gregarious distribution patterns of other marine invertebrates. Of course, as all of our bioassays were conducted in the laboratory, we must consider if the laboratory results can reflect the actual larval settlement pattern occurring in the field. The current study does give preliminary insights into how environmental cues interact with biofilms, which, in turn, influence larval settlement.

Bioassay-guided isolation and purification of larval settlement inducers and inhibitors have so far been the most powerful procedure for identification of larval settlement cues since the early 1980s (Morse \& Morse 1984, Pawlik 1990, Bryan et al. 1998, Harder \& Qian 1999, Unabia \& Hadfield 1999). Although there may be some slight variations in detailed protocols, in general, every research laboratory uses the following general procedure: (1) the waterborne compounds released by source organisms are collected and tested directly or extracted with various chemical solvents for testing or the tissues of source organisms are homogenized and extracted with various chemical solvents prior to bio- assays and then added to the testing vessels; (2) the chemical extracts are dissolved in suitable solvents (such as DMSO) and the concentration of the extracts is adjusted to the relevant 'tissue-level concentration'; (3) various dilutions or concentrates of 'tissue-level concentrations' are added into the testing vessels; (4) a given number of competent larvae of targeted marine invertebrates is added into the testing vessels to start the bioassay; (5) the test is terminated after the testing vessels, which contain larvae, seawater, and chemical extracts, are incubated for hours to days; and (6) the numbers of larvae that have settled or died in each vessel are determined to estimate the effectiveness of the extracts (or metabolites) on larval settlement induction/inhibition. Similar protocols have been used to assess the effectiveness of pharmaceutical compounds and other chemicals on larval settlement induction and inhibition. Under these testing conditions, researchers have made a big assumption that larvae are the only organisms that may interact with chemicals in the testing vessel. Therefore, larval settlement is considered as a direct response to the testing solution. This assumption has not been challenged for decades.

However, there shall not be any doubt that (1) it is very difficult to develop an axenic larval culture of marine invertebrates, particularly with planktotropic larvae because bacteria can be introduced into larval cultures through phytoplankton culture (serve as larval food) or through larvae themselves; (2) although the application of antibiotics to larval cultures will suppress bacterial growth, it will not eliminate marine bacteria; and (3) the metabolites and/or chemical extracts of marine organisms and certain pharmaceutical compounds can serve as nutrients or inhibitors for bacterial growth, depending on the bacterial consortia (Beckman et al. 1999). Therefore, as long as there are bacteria in testing vessels, addition of chemical extracts or compounds into the vessels will selectively change the bacterial community structures in the testing vessels as shown by Jin \& Qian (2004) and by this study.

There has also been convincing evidence that (1) larvae of many marine invertebrates settle in good response to biofilms (Unabia \& Hadfield 1999, Lau et al. 2002); (2) biofilm development is affected by many environmental parameters such as flow, nutrients, temperature and so on as individual bacterial species respond to changes in environmental parameters differently (Lau et al. 2005, Hung et al. in press); and (3) larval settlement response to biofilm is affected by bacterial community structures (Qian et al. 2003, Lau et al. 2005). Therefore, the development of the biofilm in testing vessels can have profound effects on bioassay results.

Overall, we strongly argue that there are very complicated triangular interactions among testing chemi- 
cals, larvae and bacteria. Ignoring the impact of bacteria on testing larvae or compounds in testing vessels will unquestionably over-simplify the relationship between larvae and chemicals and, consequently, may lead to false conclusions. Therefore, we strongly recommend that we must evaluate the effects of the chemical compounds on larvae, bacterial density, and bacterial community structures or at least monitor the bacterial density in the testing vessels in larval settlement bioassay in every laboratory. In fact, we made this argument several years ago; the main point has not received sufficient attention as of yet.

The impact of our findings can go beyond bioassay systems for larval settlement inducers and inhibitors. The presence of marine bacteria in testing vessels can also be an important issue for investigating the possible uptake of dissolved organic matter (DOM), heavy metals, and organic pollutants by marine invertebrate larvae, algae, or zooplankton. It may be a good time for us to review some of early 'important' findings in which the impact of marine bacteria on testing substances in testing vessel has been totally ignored.

In this study, we used both traditional bacterial isolation and molecular techniques to study the bacterial communities of biofilms because each method has particular advantages and disadvantages. Table 3 summarizes the results obtained by 3 methods. T-RFLP analysis showed the clear differences in bacterial community profiles between the treatments and the control. However, it is impossible to determine which bacterial group corresponds to each peak in the T-RFLP profiles without application of other techniques. In order to identify the bacterial species in the samples, it is very common to construct a clone library of bacterial communities in environmental samples (including biofilms) using the 16S rRNA gene as a phylogenetic marker. Yet, neither of these 2 methods allows us to test the bioactivity of bacteria because no bacterial isolates would be obtained by these methods. Therefore, traditional bacterial isolation and purification were required to obtain bacterial strains in larval settlement bioassays.

The DNA sequences from the clone library in this study revealed that the major bacterial group in a $2 \mathrm{~d}$ old natural biofilm is $\alpha$-Proteobacteria, while the most purified bacterial strains from the biofilm are $\gamma$-Proteobacteria. Dang \& Lovell (2000) also showed that $\alpha$-Proteobacteria were important primary surface colonizers in coastal marine waters. Bacterial isolation and purification techniques only provide cultivable bacterial species, which may be only a small proportion of the total bacterial community in a biofilm (Pace 1996). The clone library results revealed a more diversified bacterial community than that revealed by traditional bacterial isolation methods. When we compared

Table 3. Summary of T-RFLP analysis, NEBcutter analysis with the partial 16S RNA sequences from clone library and pure bacterial strains. ' + ' means the presence of the peak in the control or treatment profile. For abbreviations of amino acids see Fig. 2

\begin{tabular}{|c|c|c|c|c|c|c|c|c|c|c|c|}
\hline $\mathrm{T}-\mathrm{RF}$ & Control & Asp & Glu & Ala & Asn & Leu & Thr & Val & Ile & Clone library & Pure bacterial strains \\
\hline 70 & + & + & + & + & & & & & & & \\
\hline 78 & & & & + & & & & & & & \\
\hline 91 & + & + & + & + & & & & & & J-155 & \\
\hline 128 & + & + & + & + & + & & & & & & $\begin{array}{l}\text { Pseudoalteromonas sp. } \\
\text { UST010723-006 }\end{array}$ \\
\hline 143,144 & & + & + & + & + & & & & & & \\
\hline 183 & & & & & & & & & + & $\mathrm{J}-34$ & \\
\hline $300-304$ & + & + & + & + & + & + & + & + & + & $\begin{array}{l}\text { J-29, J-32, J-35, J-46, } \\
\text { J-89, J-96, J-100, J-131, } \\
\text { J-143, J-154 }\end{array}$ & $\begin{array}{l}\text { Roseobacter sp. (SCB28), } \\
\text { Uncultured Ruegeria CtaxMed-2, } \\
\text { Micrococcus kristinae, } \\
\text { Kocuria rhizophil, Micrococcus sp., } \\
\text { Bacillus licheniformis, } \\
\text { Vibrio halioticoli, V. nereis }\end{array}$ \\
\hline 313-315 & + & + & + & + & + & + & + & + & + & $\mathrm{J}-44, \mathrm{~J}-68, \mathrm{~J}-118$ & $\begin{array}{l}\text { Pseudoalteromonas piscicida, } \\
\text { Alteromonas alvinellae, } \\
\text { A. macleodii, } \\
\text { Pseudoalteromonas sp. }\end{array}$ \\
\hline 360 & + & & & + & + & & & & & & \\
\hline 367,368 & + & + & & & & & & & & & Tenacibaculum mesophilum \\
\hline 372,373 & + & + & + & + & + & + & + & + & + & $\begin{array}{l}\text { J-40, J-57, J-95, J-111, } \\
\text { J-116, J-132 }\end{array}$ & $\begin{array}{l}\text { Bacillus halmapal, } \\
\text { Cytophaga sp. F12, } \\
\text { Staphylococcus cohnii }\end{array}$ \\
\hline 375,376 & + & + & + & + & + & + & + & + & + & $\mathrm{J}-94$ & \\
\hline 422,423 & + & + & + & + & + & + & + & + & + & & Microbulbifer hydrolyticus \\
\hline
\end{tabular}


the results of the clone library with the T-RFLP analysis, we found that most of the sequences showed the same terminal restriction fragment (T-RF) as the one that appeared in the T-RFLP profiles. However, some T-RFs were only found in T-RFLP profiles or the clone library, indicating that neither of these techniques could reveal the complete diversity of the bacterial community. However, the sequences in the clone library indicated the possible bacterial group corresponding to the peaks in the T-RFLP profiles. For example, the T-RFs of 300-304 possibly corresponded to $\alpha$-Proteobacteria and the T-RFs of 372 and 373 possibly corresponded to CFB.

In this study, the main reason for developing a clone library was to identify the bacteria corresponding to the unique peak that appeared in amino-acid-treated biofilm. The clone library was constructed from a $2 \mathrm{~d}$ old biofilm, prior to amino acid treatment. At that point, theoretically, we should obtain all the bacterial species present in the biofilm. However, perhaps due to the technical limitations of constructing the clone library, we did not find bacterial species corresponding to all the peaks. Although the T-RFs of 143 and $144 \mathrm{bp}$ appeared only in the biofilms with increased bioactivity on larval settlement, there was no sequence information in the clone library or the pure bacterial strains showing the same T-RF profile. On the other hand, the unique T-RF of $183 \mathrm{bp}$ appeared only in Ile-treated biofilm and one of the sequences showed the same T-RF profile. Our results indicated that this bacterium may have inhibitive effects on larval settlement of Hydroides elegans. Yet, this deduction can only be confirmed after we can isolate this bacterium from a natural biofilm and test its bioactivity in larval settlement bioassays. Unfortunately, this bacterium appears to be non-cultivable with current isolation techniques and thus the question remains open at this stage.

Acknowledgements. The authors thank Drs. J. Pearse, S. C. K. Lau, J. Pechenik and lab mates for their comments on the manuscript. This study was supported by a Hong Kong Research Grants Council grant (HKUST6281/03M) to P.-Y.Q.

\section{LITERATURE CITED}

Avelin M Sr, Vitalina M Sr, Rittschof D, Nagabhushanam R (1993) Bacterial-barnacle interaction: potential of using juncellins and antibiotics to alter structure of bacterial communities. J Chem Ecol 19:2155-2167

Beckmann M, Harder T, Qian PY (1999) Induction of larval attachment and metamorphosis in the serpulid polychaete Hydroides elegans by dissolved free amino acids: mode of action in laboratory bioassays. Mar Ecol Prog Ser 190: 167-178

Bryan PJ, Qian PY, Kreider JL, Chia FS (1997) Induction of larval settlement and metamorphosis by pharmacological and conspecific associated compounds in the serpulid polychaete Hydroides elegans. Mar Ecol Prog Ser 146:81-90

Bryan PJ, Kreider JL, Qian PY (1998) Settlement of the serpulid polychaete Hydroides elegans (Haswell) on the arborescent bryozoan Bugula neritina (L.): evidence of chemically mediated relationship. J Exp Mar Biol Ecol 220:171-190

Crisp DJ (1984) Overview of research on marine invertebrate larvae, 1980-1984: In: Costlow JD, Tipper RC (eds) Marine biodeterioration: an interdisciplinary study. Naval Institute Press, Annapolis, MD, p 103-126

Dang HY, Lovell CR (2000) Bacterial primary colonization and early succession on surfaces in marine waters as determined by amplified rRNA gene restriction analysis and sequences analysis of 16S rRNA genes. Appl Environ Microbial 66:467-475

Garner MR, Flint JF, Russell JB (2002) Allisonella histaminiformans gen. nov., sp. nov: a novel bacterium that produces histamine, utilizes histidine as its sole energy source, and could play a role in bovine and equine laminitis. Syst Appl Microbiol 25:498-506

Harder T, Qian PY (1999) Induction of larval settlement and metamorphosis in the serpulid polychaete Hydroides elegans by dissolved free amino acids: isolation and identification. Mar Ecol Prog Ser 179:259-271

Harder T, Lau SCK, Dahms HU, Qian PY (2002) Isolation of bacterial metabolites as natural inducers for larval settlement in the marine polychaete Hydroides elegans (Haswell). J Chem Ecol 28:2029-2043

Hung OS, Gosselin La, Thiyagarajan V, Wu RSS, Qian PY (in press) Do effects of ultraviolet radiation on microbial films have indirect effects on larval attachment of the barnacle Balanus amphitrite. J Exp Mar Biol Ecol

Jin T, Qian PY (2004) Effect of mono-amino acids on larval metamorphosis of the polychaete Hydroides elelgans. Mar Ecol Prog Ser 267:209-218

Keough MJ, Raimondi PT (1996) Responses of settling invertebrate larvae to bioorganic films: effect of large-scale variation in films. J Exp Mar Biol Ecol 207:59-78

Kirchman D, Graham S, Reish D, Mitchell R (1982) Bacteria induce settlement and metamorphosis of Janua (Dexiospira) brasiliensis Grube (Polychaeta: Spirorbidae). J Exp Mar Biol Ecol 56:153-163

Lau SCK, Qian PY (2000) Inhibitory effect of phenolic compounds and marine bacteria on larval settlement of the barnacle Balanus amphitrite amphitrite Darwin. Biofouling 16:47-58

Lau SCK, Qian PY (2001) Larval settlement in the serpulid polychaete Hydroides elegans (Haswell) in response to bacterial film: an investigation of the nature of putative larval settlement cue. Mar Biol 138:321-328

Lau SCK, Mak KKW, Chen F, Qian PY (2002) Bioactive of bacterial strains isolated from marine biofilms in Hong Kong waters for the induction of larval settlement in the marine polychaete Hydroides elegans. Mar Ecol Prog Ser 226: 301-310

Lau SCK, Thiyagarajan V, Cheung SCK, Qian PY (2005) Roles of bacterial community composition in biofilms as a mediator for larval settlement of three marine invertebrates. Aquat Microb Ecol 38:41-51

Leitz T, Wagner T (1993) The marine bacterium Alteromonas espejiana induces metamorphosis of the hydroid Hydractinia echinata. Mar Biol 115:173-178

Maki JS, Rittschof D, Schmidt AR, Snyder AG, Michell R (1989) Factors controlling attachment of bryozoan larvae: a comparison of bacterial films and unfilmed surface. Biol Bull (Woods Hole) 177:295-302 
Matsumura K, Nagano M, Kato-Yoshinaga Y, Yamazaki M, Clare AS, Fusetani N (1998) Immunological studies on the settlement-inducing protein complex (SIPC) of the barnacle Balanus amphitrite and its possible involvement in larva-larva interactions. Proc R Soc Lond Biol Sci 265(1408):1825-1830

Morse ANC, Morse DE (1984) Recruitment and metamorphosis of Haliotis larvae induced by molecules uniquely available at the surface of crustose red algae. J Exp Mar Biol Ecol 75:191-215

O'Connor NJ, Richardson DL (1998) Attachment of barnacle (Balanus amphitrite Darwin) larvae: response to bacterial films and extracellular materials. J Exp Biol Ecol 226: $115-129$

Pace NR (1996) New prospectives on the natural microbial world: molecular microbial ecology. ASM News 62:463-470

Pawlik JR (1990) Natural and artificial induction of metamorphosis of Phragmatopoma lapidosa californica (Polychaeta: Sabellariidae), with a critical look at the effects of bioactive compounds on marine invertebrate larvae. Bull Mar Sci 46:512-536

Pawlik JR (1992) Chemical ecology of the settlement of benthic marine invertebrates. Oceanogr Mar Biol Annu Rev 30:273-335

Pearce JR, Scheibling RE (1991) Effect of macroalgae, microbial films, and conspecifics on the induction of metamorphosis of the green sea urchin, Strongylocentrotus droebachiensis (Müller). J Exp Mar Biol Ecol 147:147-162

Pechenik JA, Qian PY (1998) Onset and maintenance of metamorphic competence in the marine polychaete Hydroides

Editorial responsibility: Otto Kinne (Editor-in-Chief), Oldendorf/Luhe, Germany elegans Haswell in response to three chemical cues. J Exp Mar Biol Ecol 226:51-74

Pechenik JA, Hadfield MG, Eyster LS (1995) Assessing whether larvae of the opisthobranch gastropod Phestilla sibogae Bergh become responsive to three chemical cues at the same age. J Exp Mar Biol Ecol 191:1-17

Qian PY (1999) Larval settlement of polychaetes. Hydrobiologia 402:239-253

Qian PY, Thiyagarajan V, Lau SCK, Cheung SCK (2003) Relationship between bacterial community profiles in biofilm and attachment of the acorn barnacle Balanus amphitrite. Aquat Microb Ecol 33:225-237

Rodriguez SR, Ojeda FP, Inestrosa NC (1993) Settlement of benthic marine invertebrates. Mar Ecol Prog Ser 97:193-207

Sass H, Cypionka H (2004) Isolation of sulfate-reducing bacteria from the terrestrial deep subsurface and description of Desulfovibrio cavernae sp. nov. Syst Appl Microbiol 27:541-548

Shapiro SS, Wilk MB (1965) An analysis of variance test for normality (complete samples). Biometrika 52:591-611

Unabia CRC, Hadfield MG (1999) Role of bacteria in larval settlement and metamorphosis of the polychaete Hydroides elegans. Mar Biol 133:55-64

Wiecorek SK, Todd CD (1998) Inhibition and facilitation of settlement of epifaunal marine invertebrate larvae by microbial biofilm cues. Biofouling 12:81-118

Zar JH (1999) Biostatistical analysis, 4th edn. Prentice Hall International, Upper Saddle River, NJ

Zhou J, Bruns MA, Tiedje JM (1996) DNA recovery from soils of diverse composition. Appl Environ Microbiol 62:316-322

Submitted: November 8, 2004; Accepted: April 28, 2005

Proofs received from author(s): July 4, 2005 